\title{
Abnormal plasma fibrinolysis in patients with rheumatoid arthritis and impaired endothelial fibrinolytic response in those complicated by vasculitis
}

\author{
C S Lau, M McLaren, J Hanslip, M Kerr, J J F Belch
}

\begin{abstract}
Objectives-(a) To assess plasma fibrinolytic parameters in patients with rheumatoid arthritis (RA) and to determine whether there are differences between patients with $R A$ alone and those with RA complicated by vasculitis. (b) To determine if patients with $R A$ respond differently to venous occlusion compared with normal subjects and to assess whether such a response differs in patients with $R A$ alone and those with rheumatoid vasculitis. (c) To determine the extent of vascular damage in patients with rheumatoid vasculitis and if this correlates with the levels of plasma fibrinolytic parameters.
\end{abstract}

Methods-Sixty three patients with RA (38 had RA only and 25 had evidence of rheumatoid vasculitis) were recruited. Plasma levels of tissue plasminogen activator antigen (t-PA Ag), plasminogen activator inhibitor (PAI) activity, and factor VIII von Willebrand factor (vWF) were measured before and 10 minutes after venous occlusion.

Results-Patients with RA, with or without rheumatoid vasculitis, had higher baseline PAI levels than control subjects. The difference was statistically significant for patients with RA alone but was not statistically significant for patients with rheumatoid vasculitis. After venous occlusion, t-PA Ag levels increased significantly in normal subjects and patients with RA alone, but not in patients with rheumatoid vasculitis. Plasma levels of vWF were significantly higher in patients with rhematoid vasculitis than in normal subjects and those with $R A$ alone. In patients with $R A$ alone, baseline VWF correlated positively with t-PA Ag levels, whereas a negative correlation was found between these two parameters in patients with rheumatoid vasculitis. A negative correlation between $\mathrm{VWF}$ and t-PA Ag levels after venous occlusion was also found in patients with rheumatoid vasculitis.

Conclusions-Patients with rheumatoid vasculitis showed evidence of vascular damage with increased levels of vWF and impaired t-PA Ag release after venous occlusion, a useful measurement of endothelial reserve to remove fibrin. This may be of pathophysiological importance in the development of vasculitis in these patients.

(Ann Rheum Dis 1993; 52: 643-649)

The pathogenesis of rheumatoid arthritis (RA) is incompletely understood. In addition to altered immunity, other factors play a part. One of these may be related to defects in the formation and removal of fibrin. In normal subjects the coagulation and fibrinolytic systems are in dynamic equilibrium and fibrin clots are eventually remodelled, restoring tissue structure and function. ${ }^{1}$ In disease states characterised by increased inflammation and tissue repair, however, there is excessive fibrin formation $^{2}$ and a failure to remove fibrin in these circumstances may lead to secondary damage.

Increased levels of fibrinogen, the precursor molecule of fibrin, is a well recognised feature of $\mathrm{RA}^{3}$ and previous histopathological studies have shown the deposition of fibrin in joints of patients with RA. ${ }^{4}$ Animal studies have shown that this may be responsible for the development of secondary inflammatory changes and subsequent damage to the joint. ${ }^{5}$ Patients with RA may also present with extra-articular manifestations, and clinical vasculitis occurs in a subset of these patients. ${ }^{6}$ Systemic vasculitis is associated with high morbidity and mortality rates. ${ }^{7}$ Studies of vasculitic lesions have shown fibrin deposition within the blood vessel, which causes obliteration of the lumen and consequent death of the tissues supplied by the blood vessel. Thus fibrin could play an important part in the development of joint changes and vascular complications of RA.

We have previously shown impaired plasma fibrinolysis in some, but not all, patients with RA. ${ }^{8}$ Data from patients with rheumatoid arthritis are sparse, but suggest no significant differences in baseline in patients with rheumatoid vasculitis and those with RA alone. ${ }^{9}$ These laboratory tests were static measurements of the end result of a dynamic process, however. Furthermore, physiological variations in baseline plasma fibrinolytic factors exist; for example, there is a diurnal variation and an alteration with physical activity, ${ }^{10}$ and alimentary lipaemia. ${ }^{11}$ The 
Table 1 General characteristics of the three groups of subjects studied

\begin{tabular}{llll}
\hline Characteristic & $\begin{array}{l}\text { Normal } \\
\text { subjects } \\
(n=64)\end{array}$ & $\begin{array}{l}\text { Subjects with } \\
\text { rheumatoid } \\
\text { arthritis } \\
(n=38)\end{array}$ & $\begin{array}{l}\text { Subjects with } \\
\text { rheumatoid } \\
\text { vasculitis } \\
(n=25)\end{array}$ \\
\hline $\begin{array}{l}\text { Median (range) age (years) } \\
\text { Male : female ratio }\end{array}$ & $66(24-78)$ & $54(26-73)$ & $63(20-78)$ \\
No (\%) smokers & $22: 42$ & $12: 26$ & $8: 17$ \\
Median (range) duration of RA (years) & $17(27)$ & $10(26)$ & $11(44)$ \\
No with digital vasculitis & - & $2(1-17)$ & $7(0-39)$ \\
No with vasculitis leg ulcers & - & - & 25 \\
\hline
\end{tabular}

venous occlusion technique can avoid some of these artefacts and is a useful way of measuring the rate of endothelial cell release of fibrinolytic parameters. Changes in fibrinolytic parameters after venous occlusion in patients with RA, with or without vasculitis, have not been fully investigated previously.

In this study we assessed plasma fibrinolytic parameters before and after venous occlusion in patients with RA alone and those complicated by vasculitis. To determine if changes in fibrinolytic parameters in these patients may be related to vascular damage, levels of factor VIII von Willebrand factor (vWF), an endothelial product, were also measured.

\section{Patients and methods}

PATIENTS

Sixty three patients with RA as defined by the American Rheumatism Association criteria ${ }^{12}$ were studied. Thirty eight patients had significant but not severe symptoms of RA. All required treatment with non-steroidal antiinflammatory drugs (NSAIDs) but none was receiving or had been receiving disease modifying antirheumatic drugs (DMARDs) or steroids. In addition, none of these patients had evidence of extra-articular manifestations of RA. The other 25 patients had evidence of vasculitis. All had active digital vasculitic lesions and four had additional vasculitic leg ulcers at the time of study. Six patients were receiving no drugs for RA at presentation and the others were receiving either DMARDs (three patients) or steroids (six patients), or both (10 patients). Sixty four normal subjects matched for age, sex, and smoking habit with no significant medical illness and requiring no regular drug treatment were recruited as controls. Table 1 shows the general characteristics of the three groups of subjects studied. Table 2 shows the clinical details of patients with rheumatoid vasculitis and their treatment with drugs for RA at the time of study.

The study was approved by the Tayside committee on medical ethics and written informed consent was obtained from all subjects studied.

\section{BASELINE BLOOD SAMPLING}

All subjects attended between 9 and 10 am after a standard low fat light breakfast. All were rested for at least 30 minutes before the first venepuncture. Using a gauge 19 butterfly, blood samples were obtained without stasis at least 30 seconds after release of the tourniquet. The blood samples were anticoagulated with $3.2 \%$ trisodium citrate $(9: 1 \mathrm{v}: \mathrm{v})$ and the following assays were performed: (a) tissue plasminogen activator antigen ( $\mathrm{t}-\mathrm{PA} \mathrm{Ag}$ ) (Kabi enzyme linked immunosorbent assay (ELISA)); (b) plasminogen activator inhibitor (PAI) activity (Kabi chromogenic assay); and (c) factor VIII vWF (Dako ELISA assay).

VENOUS OCCLUSION

With the subject sitting comfortably, blood pressure was measured using a standard sphygmomanometer. The cuff pressure was then maintained at a level which was at least $10 \mathrm{mmHg}$ above the diastolic blood pressure. This prevented venous blood return from the forearm, but did not impede the flow of arterial blood. A second venous blood sample was obtained 10 minutes later from the venous

Table 2 Clinical details of patients with rheumatoid arthritis $(R A)$ complicated by vasculitis

\begin{tabular}{|c|c|c|c|c|c|c|c|c|c|}
\hline $\begin{array}{l}\text { Patient } \\
\text { No }\end{array}$ & Sex & $\begin{array}{l}\text { Age } \\
\text { (years) }\end{array}$ & $\begin{array}{l}\text { Smoking } \\
\text { (No cigarettes/ } \\
\text { day) }\end{array}$ & $\begin{array}{l}\text { Duration } \\
\text { of } R A \\
\text { (years) }\end{array}$ & $\begin{array}{l}\text { Nodular } \\
\text { disease } \\
(Y / N)\end{array}$ & $\begin{array}{l}\text { Digital } \\
\text { infarcts } \\
(Y / N)\end{array}$ & $\begin{array}{l}\text { Leg } \\
\text { ulcers } \\
(Y / N)\end{array}$ & $D M A R D s$ & $\begin{array}{l}\text { Prednisolone } \\
\text { (mg/day) }\end{array}$ \\
\hline 1 & $\mathrm{~F}$ & 78 & - & 7 & $\mathrm{Y}$ & $\mathrm{Y}$ & $\mathrm{Y}$ & - & 5 \\
\hline 2 & $\mathrm{~F}$ & 20 & - & 13 & $\mathbf{N}$ & $\mathrm{Y}$ & $\mathbf{N}$ & SASP $(2.5 \mathrm{~g} /$ day $)$ & 3 \\
\hline 3 & $\mathbf{F}$ & 67 & 6 & 4 & $\mathrm{Y}$ & $\mathrm{Y}$ & $\mathrm{Y}$ & Pen (375 mg/day) & $7 \cdot 5$ \\
\hline 4 & $\mathbf{F}$ & 45 & 20 & 6 & $\mathrm{Y}$ & $\mathrm{Y}$ & $\mathrm{N}$ & MTX (10 mg/week) & - \\
\hline 5 & $\mathrm{~F}$ & 64 & - & 39 & $\hat{\mathrm{Y}}$ & $\mathrm{Y}$ & $\mathrm{N}$ & - & 5 \\
\hline 6 & $M$ & 68 & - & 3 & $\mathrm{~N}$ & $\mathrm{Y}$ & $\mathrm{N}$ & MTX (10 mg/week) & $7 \cdot 5$ \\
\hline 7 & $M$ & 74 & - & 3 & $\mathbf{N}$ & $\mathrm{Y}$ & $\mathrm{N}$ & Aza (100 mg/day) & 10 \\
\hline 8 & $\mathrm{~F}$ & 69 & - & 25 & $\mathrm{~N}$ & $\mathrm{Y}$ & $\mathrm{N}$ & Aza (125 mg/day) & 4 \\
\hline 9 & $M$ & 55 & 20 & 8 & $\mathbf{N}$ & $\bar{Y}$ & $\mathrm{~N}$ & Pen (500 mg/day) & 3 \\
\hline 10 & $\mathbf{F}$ & 63 & 10 & 0 & $\mathbf{N}$ & $\mathrm{Y}$ & $\mathrm{N}$ & Pen (750 mg/day) & - \\
\hline 11 & $M$ & 51 & - & 11 & $\mathbf{N}$ & $\mathbf{Y}$ & $\mathrm{N}$ & - & 5 \\
\hline 12 & $\mathbf{F}$ & 52 & - & 22 & $\mathbf{N}$ & $\mathrm{Y}$ & $\mathrm{Y}$ & Aza (150 mg/day) & $2 \cdot 5$ \\
\hline 13 & $\mathbf{F}$ & 51 & - & 15 & $\mathbf{N}$ & $\mathrm{Y}$ & $\mathbf{N}$ & - & - \\
\hline 14 & $\mathbf{F}$ & 63 & 20 & 26 & $\mathrm{~N}$ & $\mathbf{Y}$ & $\mathrm{N}$ & - & - \\
\hline 15 & $\mathbf{F}$ & 71 & - & 20 & $\mathrm{~N}$ & $\mathbf{Y}$ & $\mathrm{N}$ & - & - \\
\hline 16 & $\mathbf{F}$ & 45 & - & 6 & $\mathrm{Y}$ & $\mathrm{Y}$ & $\mathbf{N}$ & HO-urea (1 g/day) & $7 \cdot 5$ \\
\hline 17 & $\mathbf{M}$ & 63 & - & 0 & $\mathbf{N}$ & $\mathrm{Y}$ & $\mathrm{N}$ & & - \\
\hline 18 & $M$ & 69 & 10 & 15 & $\mathrm{Y}$ & $\mathrm{Y}$ & $\mathrm{N}$ & MTX (10 mg/week) & $2 \cdot 5$ \\
\hline 19 & $\mathbf{F}$ & 50 & - & 2 & $\mathbf{Y}$ & $\mathrm{Y}$ & $\mathrm{N}$ & & - \\
\hline 20 & $\mathbf{F}$ & 68 & 12 & 0 & $\mathbf{N}$ & $\mathrm{Y}$ & $\mathrm{N}$ & Pen (250 mg/day) & - \\
\hline 21 & $\mathbf{M}$ & 71 & 40 & 4 & $\mathbf{N}$ & $\mathbf{Y}$ & $\mathrm{N}$ & - & 5 \\
\hline 22 & $\mathrm{~F}$ & 58 & 13 & 0 & $\mathbf{Y}$ & $\mathrm{Y}$ & $\mathrm{N}$ & - & - \\
\hline 23 & $\mathbf{M}$ & 46 & 10 & 12 & $\mathbf{N}$ & $\mathbf{Y}$ & $\mathrm{N}$ & Pen (750 mg/day) & 6 \\
\hline 24 & $\mathbf{F}$ & 26 & 12 & 5 & $\mathrm{~N}$ & $\mathbf{Y}$ & $\mathrm{Y}$ & - & 20 \\
\hline 25 & $\mathbf{F}$ & 68 & - & 25 & $\mathrm{Y}$ & $\mathbf{Y}$ & $\mathrm{N}$ & - & 5 \\
\hline
\end{tabular}

Abbreviations: $\mathrm{Y}=$ =es; $\mathrm{N}=$ no, $\mathrm{F}=$ female; $\mathrm{M}=$ male; $\mathrm{DMARDs}=$ disease modifying antirheumatic drugs; Aza=azathioprine; HOurea= hydroxyurea; $M T X=$ methotrexate; $P e n=$ penicillamine; $S A S P=$ sulphasalazine. 
Table 3 Results for plasma fibrinolytic parameters before and after venous occlusion (VO) in normal subjects, patients with rheumatoid arthritis ( $R A$ ) alone, and patients with $R A$ and vasculitis. Results are expressed as median (interquartile range)

\begin{tabular}{|c|c|c|c|c|c|}
\hline & $\begin{array}{l}\text { Normal subjects } \\
(n=64)\end{array}$ & $\begin{array}{l}\text { Patients with } \\
R A \text { alone }(n=38)\end{array}$ & $\begin{array}{l}\text { p Value } \\
\text { (patients with } \\
R A \mathrm{v} \text { normal } \\
\text { subjects) }\end{array}$ & $\begin{array}{l}\text { Patients with } \\
\text { rheumatoid } \\
\text { vasculitis }(n=25)\end{array}$ & $\begin{array}{l}\text { p Value } \\
\text { (patients with } \\
\text { rheumatoid } \\
\text { vasculitis } \mathrm{v} \\
\text { normal subjects) }\end{array}$ \\
\hline $\begin{array}{l}\text { tPA Ag before VO }(\%) \\
\text { tPA Ag after VO }(\%)\end{array}$ & $\begin{array}{l}139(100-184) \\
415(324-485) \\
{ }^{\star} p<0.00001\end{array}$ & $\begin{array}{l}126(84-165) \\
200(165-308) \\
{ }^{\star} \mathrm{p}<0.00001\end{array}$ & $\begin{array}{l}0.31 \\
<0.00001\end{array}$ & $\begin{array}{l}140(104-255) \\
189(94-323) \\
\star_{p}=0.53\end{array}$ & $\begin{array}{l}0.42 \\
<0.00001\end{array}$ \\
\hline $\begin{array}{l}\text { PAI before VO }(\mathrm{U} / \mathrm{ml}) \\
\text { PAI after VO }(\mathrm{U} / \mathrm{ml})\end{array}$ & $\begin{array}{l}11 \cdot 1(8 \cdot 1-16 \cdot 1) \\
3 \cdot 2(1 \cdot 5-10 \cdot 1) \\
{ }^{\star} \mathrm{p}<0 \cdot 00001\end{array}$ & $\begin{array}{l}16 \cdot 1(9 \cdot 6-26 \cdot 8) \\
7 \cdot 6(1-22 \cdot 7) \\
{ }^{\star} \mathrm{p}<0 \cdot 001\end{array}$ & $\begin{array}{l}<0.01 \\
0.18\end{array}$ & $\begin{array}{l}17 \cdot 7(8 \cdot 5-22 \cdot 8) \\
10 \cdot 9(1-20 \cdot 3) \\
{ }^{\star} p<0 \cdot 005\end{array}$ & $\begin{array}{l}0 \cdot 05 \\
0 \cdot 11\end{array}$ \\
\hline $\begin{array}{l}\text { vWF before VO (IU/I) } \\
\text { vWF after VO (IU/I) }\end{array}$ & $\begin{array}{l}786(560-1120) \\
1160(920-1540) \\
{ }^{\star} \mathrm{p}<0.0001\end{array}$ & $\begin{array}{l}850(630-1330) \\
1190(900-1600) \\
{ }^{\star} \mathrm{p}<0.0001\end{array}$ & $\begin{array}{l}0.58 \\
0.34\end{array}$ & $\begin{array}{l}1860(1160-2750) \\
2230(1500-4040) \\
{ }^{\star} \mathrm{p}<0.0001\end{array}$ & $\begin{array}{l}<0.0001 \\
<0.0001\end{array}$ \\
\hline
\end{tabular}

Abbreviations: $\mathrm{t}-\mathrm{PA} \mathrm{Ag}=$ tissue plasminogen activator antigen; $\mathrm{PAI}=$ plasminogen inhibitor; $\mathrm{vWF}=\mathrm{factor}$ VIII von Willebrand

${ }^{*} \mathrm{p}$ Values comparing the values before and after venous occlusion using paired Wilcoxon test.

occluded forearm before the cuff was allowed to deflate and the assays were repeated.

STATISTICAL ANALYSIS

A Mann-Whitney $U$ test was used to assess differences observed between the three groups of subjects. A paired Wilcoxon test was used to assess changes in fibrinolytic parameters before and after venous occlusion within each group of subjects. A Spearman rank test was used to assess possible correlations between fibrinolytic parameters and vWF levels at baseline and after venous occlusion.

\section{Results}

PATIENT CHARACTERISTICS

The two groups of patients with RA and the controls were matched for age, sex ratio, and smoking habit. Patients with RA alone had significantly shorter disease duration than those with rheumatoid vasculitis (median (range) $2(1-17) v 7(0-39)$ years respectively; $\mathrm{p}<0 \cdot 01)$.

FIBRINOLYSIS AT BASELINE AND AFTER VENOUS OCCLUSION

Table 3 summarises the results for plasma levels of $\mathrm{vWF}$ and fibrinolytic parameters before and after venous occlusion. Figures 1 and 2 show the changes in t-PA Ag and PAI levels before and after venous occlusion. There was no difference in baseline t-PA Ag levels between the three groups. Baseline PAI activity was significantly higher in patients with RA alone $(p<0.01)$ but did not reach a statistically significant difference in patients with rheumatoid vasculitis $(p=0.05)$ compared with normal subjects. After venous occlusion, t-PA Ag levels increased significantly in normal subjects $(p<0.00001)$ and patients with RA alone $(p<0.00001)$, but not in patients with rheumatoid vasculitis $(p=0.53)$. Levels of $t-P A$ $\mathrm{Ag}$ in patients with RA alone and those with rheumatoid vasculitis after venous occlusion were significantly lower than those in normal subjects (both $\mathrm{p}<0.00001$ ). The PAI activity decreased after venous occlusion in all three groups of subjects (controls $\mathrm{p}<0.00001$; RA $\mathrm{p}<0.001$; rheumatoid vasculitis $\mathrm{p}<0.005$ ). There was no significant difference in the levels of t-PA Ag and PAI activity before and after venous occlusion between the patients with rheumatoid vasculitis receiving different forms of treatment for RA (DMARDs alone, DMARDs and steroids, steroids alone, and no RA treatment).

\section{FACTOR VIII VON WILLEBRAND FACTOR}

There was no statistically significant difference in vWF levels between patients with RA alone and normal subjects, but patients with rheumatoid vasculitis had higher baseline levels of vWF than subjects in the other two groups (both $\mathrm{p}<0 \cdot 0001$ ). In patients with RA alone, baseline vWF levels correlated positively with $\mathrm{t}-\mathrm{PA} \mathrm{Ag}$ levels $(\mathrm{r}=0.49 ; \mathrm{p}=0.01)$. There was a significant negative correlation between baseline vWF and t-PA levels in patients with rheumatoid vasculitis, however $(\mathrm{r}=-0.54$; $\mathrm{p}=0.04)$. A negative correlation between the levels of vWF and t-PA $\mathrm{Ag}$ after venous occlusion was also found in these patients $(r=0.55 ; p=0.04)$, but there was no significant correlation between the same parameters after venous occlusion in patients with $R A$ alone $(\mathrm{r}=0.35 ; \mathrm{p}=0.08)$. No correlation between vWF and t-PA levels (before and after venous occlusion) was seen in normal subjects (tables 4 and 5). As expected, vWF levels increased significantly after venous occlusion in all subjects (all p<0.0001) (table 3 ).

\section{Discussion}

Although we and others have previously shown baseline fibrinolysis to be impaired in patients with RA, no one has yet thoroughly investigated changes in fibrinolytic parameters after venous occlusion in these patients. This is important because it is the total fibrinolytic response rather than the baseline production which determines fibrinolytic potential under conditions of clot formation. Our study has confirmed previous findings of abnormal baseline levels of fibrinolytic parameters in patients with RA. We have, for the first time, assessed endothelial t-PA release in patients with RA. Patients with rheumatoid vasculitis appeared to have a lower level of endothelial t-PA release and did not respond to venous occlusion. Levels of vWF, an endothelial product, were high in patients with rheumatoid 


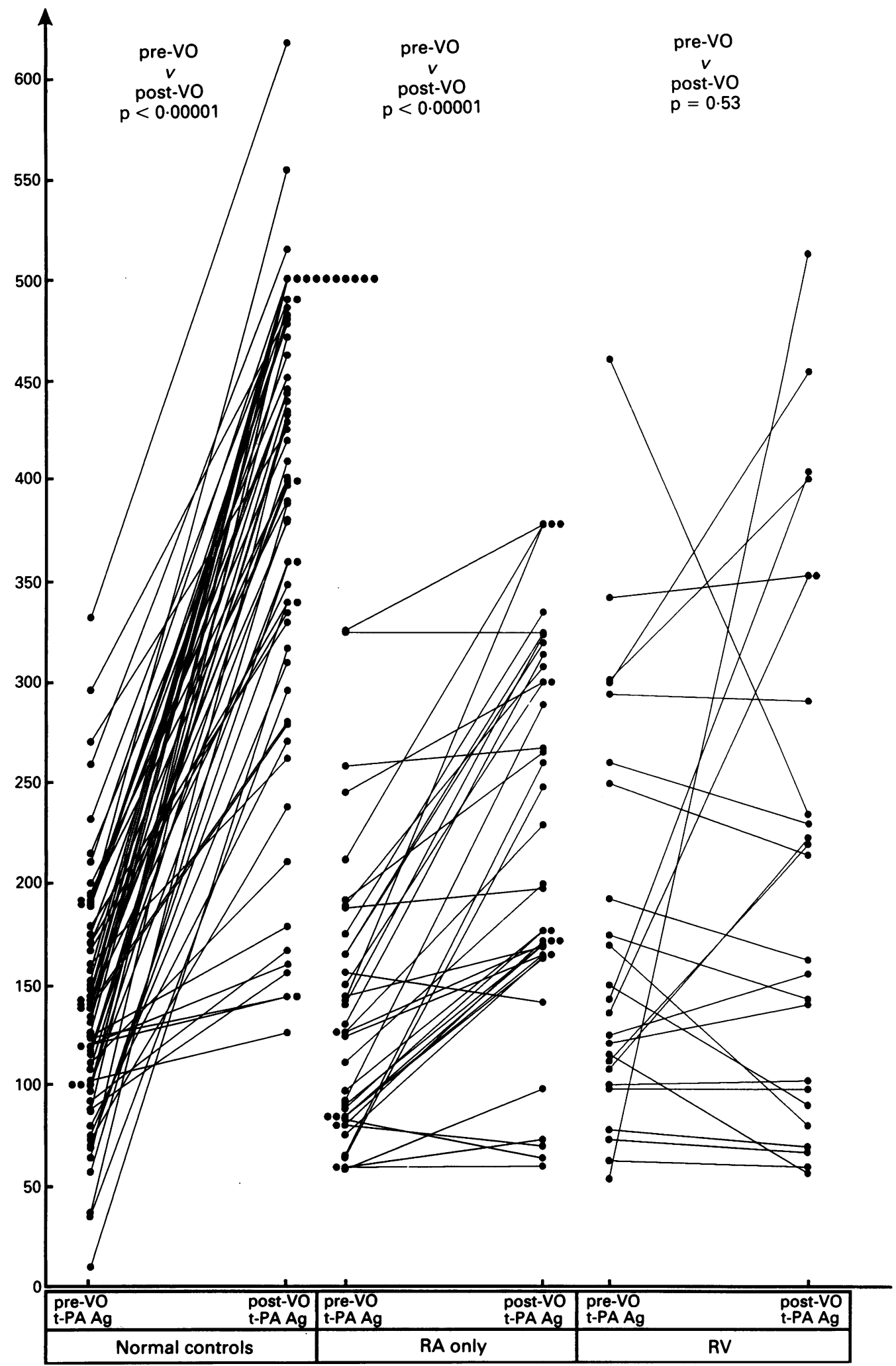

Figure 1 Plasma levels of tissue plasminogen activator antigen ( $t-P A A g$ ) before and 10 minutes after venous occlusion (VO) challenge in control subjects, patients with rheumatoid arthritis $(R A)$ alone, and patients with $R A$ and vasculitis (RV).

vasculitis. There was a negative correlation between vWF and t-PA Ag levels, at baseline and after venous occlusion, in patients with rheumatoid vasculitis. The likely reason for this is that the low t-PA reserve may be secondary to vascular damage in these patients; it is also possible, though less likely, that a predisposition to decreased t-PA production allows vascular damage to occur.

Rheumatoid arthritis is a common disorder characterised by an inflammatory arthropathy which occurs in association with systemic disease and extra-articular manifestations due to an underlying vasculitis. ${ }^{7}$ Patients with vasculitic complications have a poorer prognosis. The pathophysiology of RA and its vascular complications is not fully understood. The coagulation and fibrinolytic systems may have an important role in the development of these manifestations, however. Endothelial swelling, perivascular cellular infiltration, thrombosis, and interstitial oedema are some 


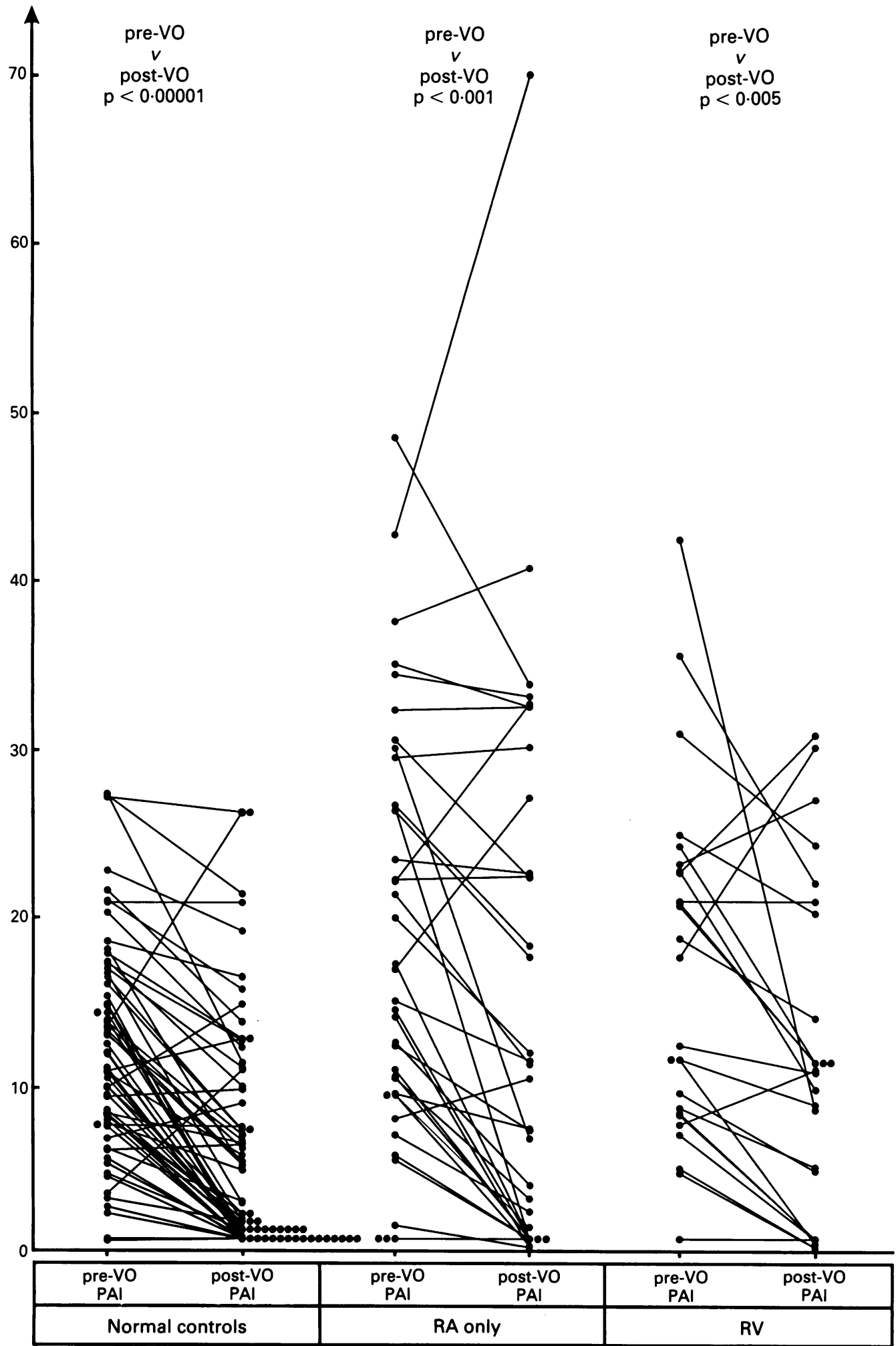

Figure 2 Plasma levels of plasminogen activator inhibitor (PAI) activity before and 10 minutes after venous occlusion (VO) challenge in control subjects, patients with rheumatoid arthritis $(R A)$ alone, and patients with $R A$ and vasculitis $(R V)$.

of the earlier synovial changes seen in patients with RA. ${ }^{413}{ }^{14}$ Early rheumatoid nodules and vasculitic lesions have fibrin deposition within the blood vessels and perivascular infiltration of inflammatory cells, ${ }^{15}$ and the therapeutic use of fibrinolytic drugs in patients with $\mathrm{RA}^{1617}$ may be useful.

The endothelium is believed to play a major part in controlling the rate of fibrinolysis. Fibrin is lysed by the action of plasmin into soluble fibrin degradation products. The rate of this reaction is dependent on the balance of the various activators and inhibitors of the formation of plasmin from its precursor molecule, plasminogen. Two important participants in this reaction are t-PA and PAI, an activator and inhibitor respectively. The main site of production of t-PA is the endothelium ${ }^{18}$ and PAI can be found in endothelial cells and in platelets and hepatocytes. ${ }^{19}$ Abnormalities of endothelial function may lead to impaired fibrinolysis and this may result in some of the damage seen in RA secondary to fibrin deposition. 
Table 4 Correlation between baseline factor VIII von Willebrand factor and plasma fibrinolytic parameters in the three groups of subjects studied. Statistical analysis was by the Spearman rank correlation coefficient test

\begin{tabular}{|c|c|c|c|c|c|c|}
\hline \multirow{2}{*}{$\begin{array}{l}\text { Plasma } \\
\text { fibrinolytic } \\
\text { parameter } \\
\text { (before venous } \\
\text { occlusion) }\end{array}$} & \multicolumn{2}{|c|}{ Normal subjects } & \multicolumn{2}{|c|}{$\begin{array}{l}\text { Patients with } \\
\text { rheumatoid arthritis }\end{array}$} & \multicolumn{2}{|c|}{$\begin{array}{l}\text { Patients with } \\
\text { rheumatoid vasculitis }\end{array}$} \\
\hline & p Value & rValue & p Value & rValue & p Value & $r$ Value \\
\hline $\begin{array}{l}\text { tPA Ag } \\
\text { PAI }\end{array}$ & $\begin{array}{l}0.58 \\
0.23\end{array}$ & $\begin{array}{r}-0.08 \\
0 \cdot 17\end{array}$ & $\begin{array}{l}0.01^{\star} \\
0.17\end{array}$ & $\begin{array}{l}0.49 \\
0 \cdot 27\end{array}$ & $\begin{array}{l}0.04^{\star} \\
0.58\end{array}$ & $\begin{array}{l}-0.54 \\
-0.15\end{array}$ \\
\hline
\end{tabular}

Abbreviations: t-PA Ag=tissue plasminogen activator antigen; $\mathrm{PAI}=$ plasminogen activator inhibitor.

^Statistically significant.

Table 5 Correlation between factor VIII von Willebrand factor and plasma fibrinolytic parameters after venous occlusion in the three groups of subjects studied. Statistical analysis was by Spearman rank correlation coefficient test

\begin{tabular}{|c|c|c|c|c|c|c|}
\hline \multirow{2}{*}{$\begin{array}{l}\text { Plasma } \\
\text { fibrinolytic } \\
\text { parameter } \\
\text { (after venous } \\
\text { occlusion) }\end{array}$} & \multicolumn{2}{|c|}{ Normal subjects } & \multicolumn{2}{|c|}{$\begin{array}{l}\text { Patients with } \\
\text { rheumatoid arthritis }\end{array}$} & \multicolumn{2}{|c|}{$\begin{array}{l}\text { Patients with } \\
\text { rheumatoid vasculitis }\end{array}$} \\
\hline & $p$ Value & $r$ Value & p Value & $r$ Value & p Value & $r$ Value \\
\hline $\begin{array}{l}\text { tPA Ag } \\
\text { PAI }\end{array}$ & $\begin{array}{l}0 \cdot 36 \\
0 \cdot 39\end{array}$ & $\begin{array}{l}0 \cdot 13 \\
0 \cdot 13\end{array}$ & $\begin{array}{l}0.07 \\
0.68\end{array}$ & $\begin{array}{l}0.35 \\
-0.08\end{array}$ & $\begin{array}{l}0.04^{\star} \\
0.09\end{array}$ & $\begin{array}{l}-0.55 \\
-0.46\end{array}$ \\
\hline
\end{tabular}

Abbreviations: t-PA Ag=tissue plasminogen activator antigen; $\mathrm{PAI}=$ plasminogen activator inhibitor.

$\star$ Statistically significant.
As most antirheumatic drugs used in RA reduce inflammatory responses in these patients, any effects of these drugs on the parameters measured here would be expected to be that of normalisation.

After venous occlusion, t-PA Ag levels increased and PAI activity decreased in normal subjects. Similar changes were observed in patients with RA alone. In patients with rheumatoid vasculitis, however, despite a decrease in PAI activity after venous occlusion, t-PA Ag levels did not increase significantly. This indicated an impairment in the endothelial t-PA release in these patients, which may be partly responsible for the pathogenesis of rheumatoid vasculitis. Although patients with RA alone were apparently able to respond to venous occlusion, it was probably subnormal compared with that from normal subjects. The t-PA levels in these patients after vascular occlusion were significantly lower than those from normal subjects, despite similar baseline levels.

Factor VIII von Willebrand factor is a product of the blood vessel wall which is released by damaged endothelium. ${ }^{25}$ We have previously shown vWF levels to be increased in patients with inflammatory vascular disease ${ }^{26} 27$ and this study confirms this by showing patients with rheumatoid vasculitis to have significantly higher baseline vWF levels than normal subjects and patients with RA alone. The fact that different levels of vWF are found in patients with different disease manifestations may partially explain discrepancies in the results of some previous reports, which showed increased levels of vWF in a heterogeneous group of patients with $\mathrm{RA} .{ }^{28}$ Other possible explanations of such discrepancies may be related to the venesection technique and to differences in treatment for RA. It is important that there is no venous stasis during venesection. All our patients with RA alone were receiving NSAIDs only.

The mechanism of endothelial damage in rheumatoid vasculitis is not fully understood. Some studies have suggested this to be mediated by polymorphonuclear cells, ${ }^{29} 30$ whereas others have found specific antibodies to endothelial cells in patients with rheumatoid vasculitis and suggested that these antibodies may play a part in the pathogenesis of the disease. ${ }^{31}$ Whatever the mechanism, damage to the blood vessel is likely to lead to dysfunction of the endothelium. It is interesting to note the significant positive correlation between $\mathrm{vWF}$ and $\mathrm{t}-\mathrm{PA} \mathrm{Ag}$ levels at baseline in the patients with RA alone. The same parameters, before and after venous occlusion, however, correlated negatively in patients with rheumatoid vasculitis and there was no correlation between them in normal subjects. These results further support the differences in endothelial function observed in the two groups of patients with RA. It is probable that patients with $R A$ are susceptible to endothelial damage by various noxious stimuli, which may then lead to the formation of a thrombus. Patients with RA alone are able to mount a t-PA release response with subsequent removal of the thrombus. 
Such a response is impaired in patients with rheumatoid vasculitis and the vasculitic thrombus persists.

Increased levels of vWF may have further clinical implications as vWF may promote thrombosis and further obstruct flow via its action on platelets ${ }^{32}$ and the clotting cascade.

In conclusion, our study has shown that patients with rheumatoid vasculitis had evidence of vascular damage with increased levels of vWF. We have shown for the first time an impaired endothelial fibrinolytic response in patients with rheumatoid vasculitis, which may be secondary to damage to the blood vessels. Our abnormal findings clearly show that patients with rheumatoid vasculitis are more likely to have a thrombus persist in the vasculature than those with $R A$ alone. We propose that this may be one of the mechanisms of the development of vasculitic complications in these patients.

We thank Ms J Lee for her secretarial assistance, Sister $\mathrm{H}$ McMahon for her help with patient assessment, and $\mathrm{Dr} M$ Wilkinson for allowing us to study his patients. This study is supported by a Scottish Hospital Endowments Research Trust Grant No 1103.

1 Astrup T. Fibrinolysis in the organism. Blood 1956; 11: 781-806

2 Astrup T, Thorsen S. The physiology of fibrinolysis. Med Clin North Am 1972; 56: 153-62.

3 Takeda Y. Studies of the metabolism and distribution of fibrinogen in patients with rheumatoid arthritis. $7 \mathrm{Lab}$ Clin Med 1969; 69: 624-33.

4 Jansani M K. Fibrin: metabolism, immunogenesis and significance in rheumatoid arthritis. In: Panayi G S, Johnston P M, eds. Immunopathogenesis of rheumatoid arthritis. Surrey: Reed Books, 1978: 137-46.

5 Dumonde D C, Glynn L E. The production of arthritis in rabbits by an immunological reaction to fibrin. $B r \mathcal{F} E x$ Pathol 1962; 43: 373-8.

6 Cawley M I. Vasculitis and ulceration in rheumatic disease of the foot. Baillieres Clin Rheumatol 1987; 1: 315-33

7 Vollertsen R S, Conn D L, Ballard D J, Ilstrup D M Kazmar R E, Silverfield J C. Rheumatoid vasculitis: survival and associated risk factors. Medicine (Baltimore) 1986; 65: 365-75.

8 Belch J J F, McArdle B, Madhok R, et al. Decreased plasma fibrinolysis in patients with rheumatoid arthritis. Ann Rheum Dis 1984; 43: 774-7.

9 Conn D L, McDuffie F C, Kazmier F J, Schroeter A L, Sun N C J. Coagulation abnormalities in rheumatoid disease. Arthritis Rheum 1976; 19: 1237-43.

10 Fearnley G R, Balmforth G, Fearnley E. Evidence of diurnal fibrinolytic rhythm with a simple method of measuring natural fibrinolysis. Clin Sci 1957; 16: 645-50.

11 Belch J J F, Saniabadi A R, McLaren M McLaughlin K, Forbes C D. Acute platelet changes after a saturated fat meal and their prevention by UK 38,485 , a potent thromboxane synthetase inhibitor. Lipids 1987; 22: 159-62.

12 Arnett F C, Edworthy S M, Bloch D A, et al. The American Rheumatism Association 1987 revised criteria for the classification of rheumatoid arthritis. Arthritis Rheum 1988; 31: 315-24.

13 Kulka J P, Bocking D, Ropes M W, Bauer W. Early join lesions of rheumatoid arthritis. A report of eight cases, with knee biopsies in lesions of less than one yea duration. Arch Pathol 1955; 59: 129-50.

14 Schumacher H R, Kitridou R C. Synovitis of recent onset. A clinicopathologic study during the first month of disease. Arthritis Rheum 1972; 15: 465-85.

15 Hough A J, Sokoloff L. Pathology. In: Utsinger P D, Zvaifle N J, Ehrlich G E, eds. Rheumatoid arthritis. Philadelphia, Lippincott, 1985: 49-69.

16 Fearnley G R, Chakrabarti R, Evans J F. Fibrinolytic treatment of rheumatoid arthritis with phenformin plus treatment of rheumatoid arthritis with

17 Belch J J F, Madhok R, McArdle B, McLaughlin K, Forbe C D, Sturrock R D. The effect of increasing fibrinolysis in patients with rheumatoid arthritis: a double-blind study of stanozolol. Qf Med 1986; 58: 19-27.

18 Loskutoff D J. The fibrinolytic system of cultured endothelial cells: insights into the role of endothelium in thrombolysis. In: Gimbrone M A, ed. Vascular endothelium in hemostasis and thrombosis. Edinburgh: Churchill Livingstone, 1986: 120-42.

19 Sprengers E D, Kluft C. Plasminogen activator inhibitors. Blood 1987; 69: 381-7.

20 Belch J J F, Zoma A, McLaughlin K, et al. Fibrinolysis in SLE: effect of desamino-D-arginine vasopressin infusion. SLE: effect of desamino-D-arginin

21 Robertson B R, Pandolfi M, Nilsson I M. 'Fibrinolytic capacity' in healthy volunteers at different ages as studied by standardized venous occlusion of arms and legs. Acta Med Scand 1972; 191: 199-202.

22 McLaren M, Jennings P E, Forbes C D, Belch J J F. Fibrinolytic response to venous occlusion in diabetics with and without microangiography compared to normal age and sex matched controls. Fibrinolysis 1990; 4: 95-6.

23 Awada H, Barlowatz-Meimon G, Dougados M Maisonneuve P, Sultan Y, Amor B. Fibrinolysis Maisonneuve P, Sultan Y, Amor B. Fibrinolysis abnormalities in systemic lupus erythematous and thei

24 Chakrabarti R, Fearnley G R, Hocking E D. Effects of corticosteroid therapy on fibrinolysis in patients with inflammatory and non-inflammatory conditions. $B M$ 1964; $1: 534-7$.

25 Tuddenham E C D, Lazarchick J, Hoyer L W. Synthesis and release of Factor VIII by cultured endothelial cells. $\mathrm{Br} f$ Haematol 1981; 47: 617-26.

26 Belch J J F, Zoma A A, Richards I M, McLaughlin K, Forbes C D, Sturrock R D. Vascular damage and Factor VIII related antigen in the rheumatic diseases. Rheumatol Int 1987; 7: 107-11.

27 Lau C S, McLaren M, Belch J J F. Factor VIII von Willebrand factor antigen levels correlate with symptom severity in patients with Raynaud's phenomenon. $\mathrm{Br} f$ Rheumatol 1991; 30: 433-6.

28 Nusinow S R, Federici A B, Zimmerman T S, Curd J G. Increased von Willebrand factor antigen in the plasma of patients with vasculitis. Arthritis Rheum 1984; 27: 1405-10.

29 Fantone J C, Ward P A. Polymorphonuclear leukocytemediated cell and tissue injury: oxygen metabolites and mediated cell and tissue injury: oxygen metabolites and their relat 8 .

30 Breedveld F C, Heurkens A H, Lafeber G J, van Hinsbergh $\mathrm{VW}$, Cats A. Immune complexes in sera from patients with rheumatoid vasculitis induce polymorphonuclear cell-mediated injury to endothelial cells. Clin Immuno Immunopathol 1988; 48: 202-13.

31 Heurkens A H M, Hiemstra G J M, Lafeber M R, Daha M R, Breedveld F C. Anti-endothelial cell antibodies in patients with rheumatoid arthritis complicated by vasculitis. Clin Exp Immunol 1989; 78: 7-12.

32 DeMarco L Girolami A, Ruggeri Z M. Platelet aggregation induced by asialo von Willebrand factor: the role of fibrinogen. Blood 1983; 62: 254a. 